\title{
SUBSTITUSI TEPUNG UBI JALAR UNGU DAN TEPUNG TEMPE PADA BOLU CUKKE MERUPAKAN ALTERNATIF PMT UNTUK IBU HAMIL DAN BALITA
}

\author{
Manjilala $^{\varpi}$, Mustamin \\ Jurusan Gizi Poltekkes Kemenkes Makassar
}

\begin{tabular}{l}
\hline ARTICLE INFO \\
\hline Article history \\
Submitted : 2021-10-24 \\
Revised : 2021-10-29 \\
Accepted : 2021-12-29 \\
Keywords: \\
Bolu cukke \\
Sweet potato flour \\
Tempe flour \\
\\
Kata Kunci: \\
Bolu cukke \\
Tepung ubi jalar ungu \\
Tepung tempe
\end{tabular}

\begin{abstract}
Supplementary food, especially for vulnerable groups such as pregnant women and toddlers, is one strategy in dealing with nutritional problems, especially during the COVID-19 pandemic. The aim of the study was to determine the acceptability of Bolu Cukke with purple sweet potato flour and tempeh flour substitutes. Experimental research was conducted at the Food Technology Laboratory, Department of Nutrition, Poltekkes, Ministry of Health Makassar with a total of 50 panelists in 2019. The nutritional content was analyzed using the Kjhedal method for protein, gravimetry for fat, and titrimetry for carbohydrates. Acceptance test was analyzed using KruskalWallis and Mann-Whitney test with 95\% confidence level. The results showed that the color and aroma of the four sample groups were different $(\mathrm{p}=0.000$ and $\mathrm{p}=0.028)$, while there was no difference in texture and taste. Based on the nutritional content, group $\mathrm{C}$ had the highest protein content, group A had the highest fat content while group D had the highest carbohydrate content.
\end{abstract}

Makanan tambahan khususnya bagi kelompok rentan seperti ibu hamil dan balita merupakan salah satu strategi dalam menghadapi masalah gizi terutama di masa pandemi covid-19. Penelitian bertujuan untuk melihat daya terima Bolu Cukke dengan substitusi tepung ubi jalar ungu dan tepung tempe. Penelitian eksperimen dilakukan di Laboratorium Teknologi Pangan Jurusan Gizi Poltekkes Kemenkes Makassar dengan jumlah panelis 50 orang pada tahun 2019. Kandungan gizi dianalisis menggunakan metode Kjhedal untuk protein, gravimetri untuk lemak, dan titrimetri untuk karbohidrat. Uji daya terima dianalisis menggunakan uji Kruskal-Wallis dan Mann-Whitney dengan tingkat kepercayaan 95\%. Hasil penelitian menunjukkan bahwa warna dan aroma pada keempat kelompok sampel berbeda ( $\mathrm{p}=0,000$ dan $\mathrm{p}=0,028)$, sedangkan tekstur dan rasa tidak terdapat perbedaan. Berdasarkan kandungan gizi, kelompok $\mathrm{C}$ memiliki kandungan protein tertinggi, kelompok A memiliki kandungan lemak tertinggi sedangkan kandungan karbohidrat tertinggi pada kelompok D.

\footnotetext{
$\triangle$ Corresponding Author:
}

\author{
Manjilala \\ Jurusan Gizi Poltekkes Kemenkes Makassar \\ Telp. 085255549979 \\ Email: manjilala@poltekkes-mks.ac.id
}

\section{PENDAHULUAN}

Hasil Pemantauan Status Gizi (PSG) tahun 2015-2017 yang dilaksanakan oleh Kementerian Kesehatan RI menunjukkan bawah terjadi penurunan prevalensi balita kurus di Indonesia yaitu sebanyak $12,0 \%$ pada tahun 2015, menjadi $11,1 \%$ pada tahun 2016 dan 9,6\% pada tahun 2017. Meskipun demikian, jika dibandingkan dengan standar WHO, prevalensi tersebut masih menjadi masalah kesehatan masyarakat dengan kategori masalah sedang. Berbeda dengan balita pendek, prevalensi tiga tahun terakhir mengalami peningkatan, dari $29,0 \%$ pada tahun 2015 , turun menjadi $27,5 \%$ pada tahun 2016 dan meningkat lagi menjadi $29,6 \%$ pada tahun 2017. Jika dibandingkan dengan standar WHO, prevalensi tersebut masih menjadi masalah kesehatan masyarakat dengan kategori masalah sedang (Dinkes Prop. Sulsel, 2017).

Provinsi Sulawesi Selatan juga mengalami kondisi yang hampir sama dengan kondisi Nasional, terjadi penurunan prevalensi balita kurus dari tahun 2015 - 2017, yaitu $10,8 \%$ pada tahun 2015 , menjadi $9,3 \%$ pada tahun 2016 dan 8,7\% pada tahun 2017. Balita pendek juga mengalami penurunan, yaitu $34,1 \%$ pada tahun 2015 , menjadi $35,6 \%$ pada tahun 2016 dan $34,8 \%$ pada tahun 2017. Sedangkan status gizi ibu hamil pada tahun 
2017 menunjukkan bahwa masih terdapat sekitar $15,9 \%$ ibu hamil yang memiliki risiko Kekurangan Energi Kronik (KEK) (Dinkes Prop. Sulsel, 2017).

Tingkat asupan energi pada balita di tahun 2017 hanya 24,9\% yang cukup, asupan protein yang cukup sebanyak 50,5\%, lemak sebanyak $22,6 \%$ dan karbohidrat sebanyak 24,6\%. Rendahnya tingkat asupan pada balita secara langsung mempengaruhi status gizi balita yang pada akhirnya akan mempengaruhi pertumbuhan dan perkembangannya (Dinkes Prop. Sulsel, 2017).

Masalah gangguan tumbuh kembang pada balita khususnya usia di bawah dua tahun perlu mendapat perhatian khusus mengingat pada periode tersebut merupakan periode kritis proses pertumbuhan dan perkembangan anak, di samping itu balita kurus dan pendek akan berdampak pada penampilan anak saat memasuki usia sekolah. Sedangkan ibu hamil yang memiliki risiko KEK akan berdampak terhadap pertumbuhan dan perkembangan janin yang dikandungnya (Kemenkes, 2017).

Salah satu strategi dalam mengatasi masalah gizi ialah dengan cara pemberian makanan tambahan khususnya bagi kelompok berisiko seperti ibu hamil dan anak balita. Berdasarkan hal tersebut beberapa hal yang perlu menjadi perhatian serius dalam pencegahan BBLR dan masalah gizi lainnya ialah ketersediaan zat gizi mikro dan makro pada sebuah produk PMT (Kemenkes, 2017).

Pemberian makanan tambahan pada balita memberi efek peningkatan status gizi pada balita di beberapa Negara, peningkatan berat badan lebih baik jika disertai dengan intervensi edukasi gizi berbasis pangan lokal (Kemenkes, 2017). Hasil penelitian Manjilala, dkk (2017) menunjukkan bahwa bolu cukke substitusi tepung ubi jalar ungu bisa menjadi alternatif PMT lokal buat ibu hamil KEK dan Balita kurus, hanya saja kandungan protein pada kue terebut perlu ditingkatkan. Oleh karena itu pada penelitian ini kami tertarik untuk mencoba menambahkan tepung tempe agar kandungan protein Bolu cukke substitusi tepung ubi jalar ungu bisa lebih baik.

Tujuan penelitian ini adalah untuk memperoleh informasi tentang daya terima masyarakat serta kandungan gizi bolu cukke substitusi tepung tempe dan tepung ubi jalar ungu.

\section{METODE}

Metode penelitian yang digunakan ialah praeksperimen dengan desain post test group design. Pembuatan produk dan uji daya terima dilakkan di Laboratorium Teknologi Pangan Jurusan Gizi Poltekkes Kemenkes Makassar, sedangkan analisis kandungan gizi dilakukan di Laboratorium Politeknik Negeri Makassar pada tahun 2019. Sebanyak 50 panelis yang terdiri atas mahasiswa dan dosen Poltekkes Makassar.

\section{Prosedur penelitian}

Penelitian dilakukan dengan beberapa tahapan antara lain pembuatan tepung tempe dan tepung ubi jalar ungu, selanjutnya tahap kedua ialah pembuatan bolu cukke. Tahap berikutnya ialah penilaian oleh panelis dilanjutkan dengan analisis nilai gizi, pengolahan dan analisis data serta penyusunan laporan penelitian.

Tabel 1. Bahan Pembuatan Bolu Cukke Substitusi Tepung Ubi Jalar Ungu dan Tepung Tempe berdasarkan Kelompok Sampel/Perlakuan

\begin{tabular}{lcccc}
\hline \multirow{2}{*}{ Bahan } & \multicolumn{4}{c}{ Perlakuan/Kelompok Sampel } \\
\cline { 2 - 5 } & $\mathbf{O}_{2} \mathbf{A}$ & $\mathbf{O}_{2} \mathbf{B}$ & $\mathbf{O}_{2} \mathbf{C}$ & $\mathbf{O}_{2} \mathbf{D}$ \\
\hline Gula Aren & $400 \mathrm{~g}$ & $400 \mathrm{~g}$ & $400 \mathrm{~g}$ & $400 \mathrm{~g}$ \\
Telur Ayam & $5 \mathrm{butir}$ & $5 \mathrm{butir}$ & $5 \mathrm{butir}$ & $5 \mathrm{butir}$ \\
Tepung Ubi Jalar Ungu & $0 \mathrm{~g}$ & $150 \mathrm{~g}$ & $225 \mathrm{~g}$ & $300 \mathrm{~g}$ \\
Tepung Tempe & $0 \mathrm{~g}$ & $60 \mathrm{~g}$ & $60 \mathrm{~g}$ & $60 \mathrm{~g}$ \\
Tepung Terigu & $300 \mathrm{~g}$ & $150 \mathrm{~g}$ & $75 \mathrm{~g}$ & $0 \mathrm{~g}$ \\
\hline
\end{tabular}

\section{Analisis Zat Gizi}

1. Metode Kjeldahl untuk kandungan protein.

2. Metode Soxhlet (AOAC, 2005) untuk kandungan lemak.
3. Metode Luff Schoorl untuk kandungan karbohidrat 


\section{Pengolahan dan Analisis Data}

Uji Kruskal-Wallis dipilih untuk melihat apakah ada perbedaan daya terima pada keempat kelompok sampel, untuk melihat perbedaan pada dua kelompok sampel dipilih uji Mann-Whitney. Alasan penggunaan uji Kruskal-Wallis ialah karena data daya terima terdiri atas data ordinal (sangat tidak suka, tidak suka, suka, sangat suka) yang terdiri atas 4 kelompok sampel.

\section{HASIL PENELITIAN}

Tabel 2. Daya Terima Bolu Cukke Substitusi Tepung Ubi Jalar dan Tepung Tempe

\begin{tabular}{|c|c|c|c|c|c|c|c|c|}
\hline \multirow{2}{*}{ Kategori Sampel $^{1)}$} & \multicolumn{2}{|c|}{ Warna } & \multicolumn{2}{|c|}{ Aroma } & \multicolumn{2}{|c|}{ Tekstur } & \multicolumn{2}{|c|}{ Rasa } \\
\hline & $\mathbf{n}$ & $\%$ & $\mathbf{n}$ & $\%$ & $\mathbf{n}$ & $\%$ & $\mathbf{n}$ & $\%$ \\
\hline \multicolumn{9}{|l|}{ Sampel A } \\
\hline Tidak Suka & 2 & 4,0 & 10 & 20,0 & 6 & 12,0 & 8 & 16,0 \\
\hline Suka & 48 & 96,0 & 40 & 80,0 & 44 & 88,0 & 42 & 84,0 \\
\hline \multicolumn{9}{|l|}{ Sampel B } \\
\hline Tidak Suka & 10 & 20,0 & 7 & 14,0 & 15 & 30,0 & 10 & 20,0 \\
\hline Suka & 40 & 80,0 & 43 & 86,0 & 35 & 70,0 & 40 & 80,0 \\
\hline \multicolumn{9}{|l|}{ Sampel C } \\
\hline Tidak Suka & 13 & 26,0 & 7 & 14,0 & 14 & 28,0 & 8 & 16,0 \\
\hline Suka & 37 & 74,0 & 43 & 86,0 & 36 & 72,0 & 42 & 84,0 \\
\hline \multicolumn{9}{|l|}{ Sampel D } \\
\hline Tidak Suka & 16 & 32,0 & 19 & 38,0 & 15 & 30,0 & 6 & 12,0 \\
\hline Suka & 34 & 68,0 & 31 & 62,0 & 35 & 70,0 & 44 & 88,0 \\
\hline
\end{tabular}

Tabel 2 menunjukkan bahwa keempat kelompok sampel disukai oleh Sebagian besar panelis, yaitu masing-masing 96,0\% pada Sampel A (Tepung Ubi Jalar dan Tepung tempe $0 \%$ ), sebanyak $80,0 \%$ pada sampel B (Tepung Ubi Jalar 50\%, Tepung tempe 20\%), 74,0\% pada sampel C (Tepung Ubi Jalar 75\%, Tepung tempe $20 \%$ ) serta $68,0 \%$ pada sampel D (Tepung Ubi Jalar 100\%, Tepung tempe 20\%).

Hasil uji Kruskal-Wallis menunjukkan bahwa keempat kelompok sampel memiliki warna yang berbeda $(p=0,000)$, uji lanjut dilakukan untuk mengetahui warna yang berbeda pada keempat kelompok sampel, hasil uji menunjukkan bahwa sampel A memiliki warna yang berbeda dengan ketiga kelompok sampel lainnya.

Berdasarkan nilai Mean Rank atau rata-rata peringkat tiap kelompok pada uji
Panelis pada penelitian ini terdiri atas Mahasiswa dan dosen Poltekkes Kemenkes Makassar yang terdiri atas 50 panelis. Sebagian besar panelis berjenis kelamin perempuan $(84,0 \%)$, rata-rata berusia 20 tahun serta sebagian besar $(90,0 \%)$ sudah mengenal rasa, warna, aroma dan tekstur Bolu cukke gula merah.

Hasil uji daya terima berdasarkan empat aspek cita rasa (warna, aroma, tekstur dan rasa) dapat dilihat pada tabel 2 . 
Tabel 3. Hasil Analisis Statistik Kruskal-Wallis

\begin{tabular}{|c|c|c|c|c|c|}
\hline \multicolumn{6}{|c|}{ Kruskal-Wallis Test } \\
\hline & \multicolumn{2}{|c|}{ Sampel } & $\mathbf{N}$ & \multicolumn{2}{|c|}{ Mean Rank } \\
\hline \multirow{4}{*}{ Warna } & \multicolumn{2}{|c|}{ Sampel A } & 50 & \multicolumn{2}{|c|}{131,98} \\
\hline & \multicolumn{2}{|c|}{ Sampel B } & 50 & \multicolumn{2}{|c|}{97,46} \\
\hline & \multicolumn{2}{|c|}{ Sampel C } & 50 & \multicolumn{2}{|c|}{97,17} \\
\hline & \multicolumn{2}{|c|}{ Sampel D } & 50 & \multicolumn{2}{|c|}{75,39} \\
\hline \multirow{4}{*}{ Aroma } & \multicolumn{2}{|c|}{ Sampel A } & 50 & \multicolumn{2}{|c|}{108,30} \\
\hline & \multicolumn{2}{|c|}{ Sampel B } & 50 & \multicolumn{2}{|c|}{107,11} \\
\hline & \multicolumn{2}{|c|}{ Sampel C } & 50 & \multicolumn{2}{|c|}{105,54} \\
\hline & \multicolumn{2}{|c|}{ Sampel D } & 50 & \multicolumn{2}{|c|}{81,05} \\
\hline \multirow{4}{*}{ Tekstur } & \multicolumn{2}{|c|}{ Sampel A } & 50 & \multicolumn{2}{|c|}{104,72} \\
\hline & \multicolumn{2}{|c|}{ Sampel B } & 50 & \multicolumn{2}{|c|}{97,05} \\
\hline & \multicolumn{2}{|c|}{ Sampel C } & 50 & \multicolumn{2}{|c|}{109,18} \\
\hline & \multicolumn{2}{|c|}{ Sampel D } & 50 & \multicolumn{2}{|c|}{91,05} \\
\hline \multirow{4}{*}{ Rasa } & \multicolumn{2}{|c|}{ Sampel A } & 50 & \multicolumn{2}{|c|}{102,34} \\
\hline & \multicolumn{2}{|c|}{ Sampel B } & 50 & \multicolumn{2}{|c|}{90,78} \\
\hline & Samp & & 50 & &, 38 \\
\hline & Samp & & 50 & &, 50 \\
\hline & & Stat & $i^{i c s}{ }^{a, b}$ & & \\
\hline & Warna & Aro & & Tekstur & Rasa \\
\hline Chi-Square & 29,481 & 9,0 & & 3,285 & 2,600 \\
\hline df & 3 & 3 & & 3 & 3 \\
\hline Asymp. Sig &, 000 & ,02 & & ,350 & ,458 \\
\hline
\end{tabular}

Berdasarkan nilai Mean Rank atau ratarata peringkat tiap kelompok pada uji KruskalWallis, diperoleh informasi bahwa nilai Mean Rank pada kelompok sampel A lebih tinggi $(108,30)$ dari ketiga kelompok sampel lainnya, jika ketiga kelompok substitusi tepung ubi jalar ungu dan tepung tempe dibandingkan (Sampel B, C dan D) maka kelompok sampel B memiliki aroma yang lebih disukai oleh panelis. Sebagian besar panelis menyukai tekstur Bolu cukke substitusi tepung ubi jalar ungu dan tepung tempe. Uji Kruskal-Wallis menunjukkan bahwa tekstur keempat kelompok sampel relatif sama $(p=0,350)$.

Berdasarkan nilai Mean Rank pada uji Kruskal-Wallis, diperoleh informasi bahwa nilai Mean Rank pada kelompok sampel C lebih tinggi $(109,18)$ dari ketiga kelompok sampel lainnya, berdasarkan aspek tekstur, kelompok C lebih disukai oleh panelis. Sebagian besar panelis memberi penilaian suka pada rasa keempat kelompok, yang terbanyak pada kelompok sampel D. Uji Kruskal-Wallis juga menunjukkan bahwa rasa keempat kelompok sampel relatif sama $(p=0,458)$. Berdasarkan nilai rata-rata peringkat tiap kelompok pada uji Kruskal-Wallis, diperoleh informasi bahwa nilai Mean Rank pada kelompok sampel C lebih tinggi $(107,38)$ dari ketiga kelompok sampel lainnya.

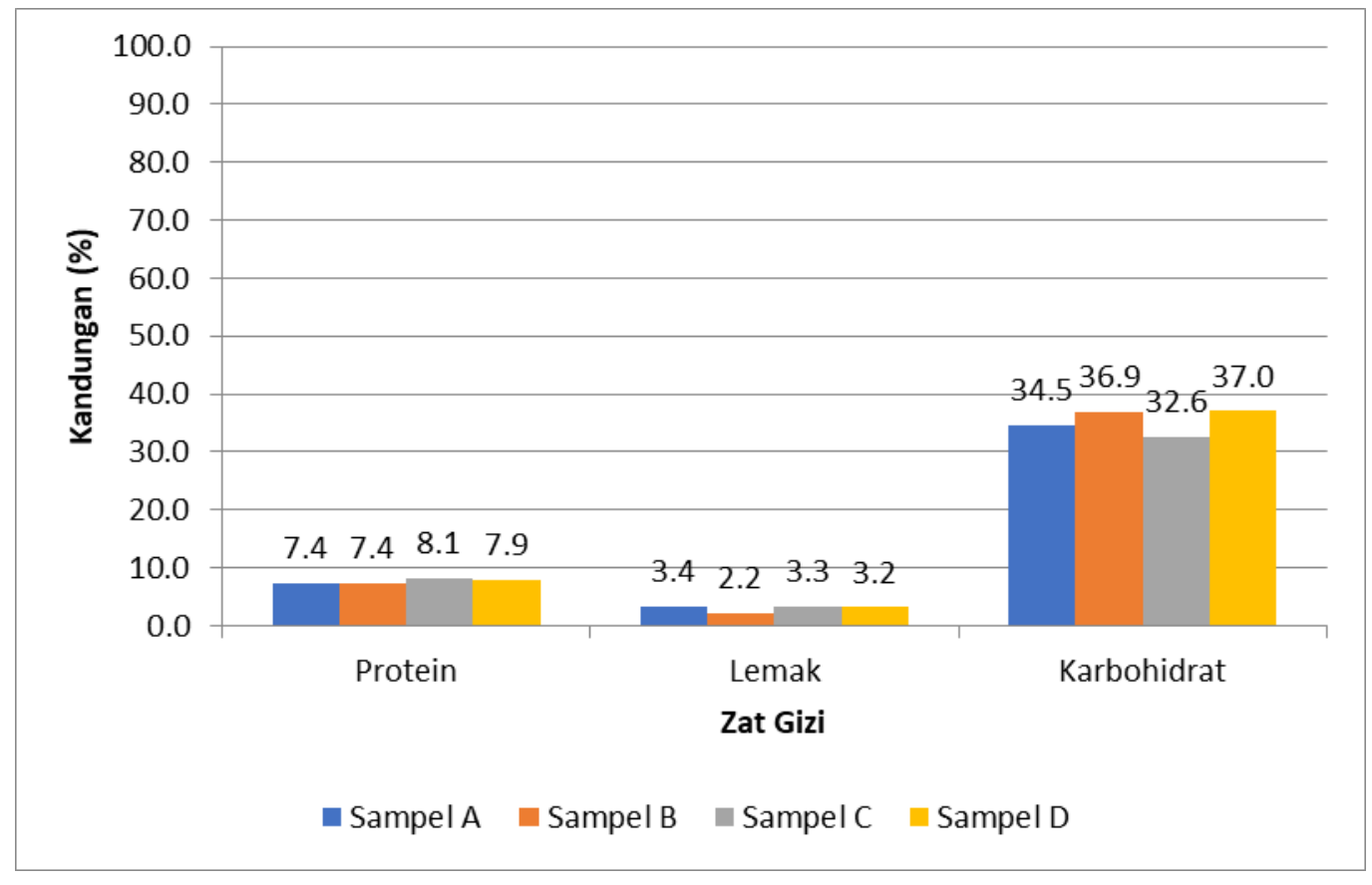

Gambar 1. Kandungan Gizi Bolu Cukke Substitusi Tepung Ubi Jalar Ungu dan Tepung Tempe 
Kandungan gizi Bolu Cukke dianalisis di Balai Besar Laboratorium Kesehatan Makassar. Metode yang digunakan ialah metode Kjehdal untuk mengetahui kandungan protein, metode Gravimetrik untuk mengetahui kandungan lemak serta metode Titrimetrik untuk mengetahui kandungan karbohidrat. Hasil analisis kandungan gizi dapat dilihat pada gambar 1.

Gambar tersebut menunjukkan bahwa kandungan kelompok sampel $\mathrm{C}$ memiliki kandungan protein tertinggi dan terendah pada kelompok sampel A dan B. Sedangkan kandungan lemak tertinggi pada kelompok sampel C dan terendah pada sampel B. Kandungan karbohidrat, tertinggi pada kelompok sampel D dan terendah pada sampel C.

\section{PEMBAHASAN \\ Daya Terima}

Provinsi Sulawesi Selatan memiliki keragaman dan kekayaan makana lokal yang dapat dimanfaatkan sebagai makanan tambahan untuk kelompok berisiko seperti ibu hamil dan balita, salah satunya ialah Bolu Cukke. Kue tradisional ini memiliki bahan utama yaitu tepung terigu dan bahan tambahan lainnya, dimana bahan-bahan tersebut diolah sedemikian rupa lalu dimasak menggunakan pemanggang alat khusus.

Penggunaan tepung terigu pada Bolu Cukke dapat diganti atau dikombinasi dengan jenis tepung lain, seperti tepung ubi jalar ungu. Penggunaan tepung ubi jalar ungu bertujuan agar mengurangi penggunaan tepung terigu yang bahan bakunya berasal gandum dan harus diimpor, di samping itu juga untuk menambah manfaat bagi produk (Hal, M. van. 2000; Jiang, X. 2001).

Beberapa penelitian menunjukkan bahwa penggunaan tepung ubi jalar ungu pada berbagai macam makanan tradisional sangat dimungkinkan termasuk pada pembuatan jenang dan menyubstitusi $50 \%$ tepung ketan (Ginting et al. 2015). Hasil penelitian kami juga menunjukkan bahwa sesuai aspek warna serta aroma, bolu cukke substitusi tepung ubi jalar $50 \%$ serta tepung tempe 20\% (sampel B) lebih disukai, tapi berdasarkan aspek tekstur, bolu cukke substitusi tepung ubi jalar 75\% serta tepung tempe $20 \%$ (sampel C) lebih disukai, sedangkan berdasarkan aspek rasa, bolu cukke substitusi tepung ubi jalar $100 \%$ dan tepung tempe $20 \%$ (sampel D) lebih disukai.

Hal tersebut menunjukkan bahwa untuk memperoleh bolu cukke substitusi tepung ubi jalar dan tepung tempe terbaik ialah $50 \%$ atau $75 \%$ tepung ubi jalar ungu dan tepung tempe $20 \%$ (sampel B atau C). Penelitian sebelumnya menunjukkan bahwa penambahan tepung ubi jalar ungu pada pembuatan bolu gulung memberi rasa, warna serta tekstur yang disukai oleh panelis, khususnya pada penambahan $50 \%$ tepung ubi jalar ungu. (Anton Ramadhan Ketra serta Okta Wulandra, 2015).

Pengolahan tempe menjadi tepung mempunyai banyak manfaat, diantaranya tepung tempe mudah dicampur dengan sumber karbohidrat buat memperkaya nilai gizinya, praktis disimpan ataupun diolah sebagai kuliner cepat saji (Albab, S. U. dan Susanto, W. H. 2016; Aristawati, R., dkk. 2013; Bastian, F., dkk., 2013).

Tepung tempe merupakan turunan dari Tempe makanan tradisional Indonesia yang tergolong sebagai generasi kedua. Produk akhir sudah jauh berbeda dengan produk asal sehingga rasa dan warna tidak muncul lagi. (Dwinaningsih, E. A. 2010; James, E. O.,et.al., 2013; Murdiati, A.,dkk., 2015).

Hal tersebut yang menyebabkan mengapa bolu cukke substitusi Tepung ubi jalar ungu dan tepung tempe ini menampilkan tekstur dan rasa yang tidak berbeda dengan kelompok kontrol ataupun dengan kelompok sampel lainnya. Meskipun beberapa penelitian menunjukkan bawah penggunaan tepung tempe sebagai substitusi tepung terigu dapat menimbulkan rasa pahit (getir) sehingga menghambat proses pengembangan tepung tempe.

Rasa pahit tersebut timbul karena adanya komponen pahit, media rasa pahit, interaksi rasa dan etanol. Akan tetapi dengan pengolahan yang tepat serta penambahan tepung ubi jalar ungu rasa pahit yang ditimbulkan oleh tepung tempe dapat dikurangi (Murtiningrum, dkk., 2012; Puteri, dkk., 2015).

\section{Kandungan Gizi}

Nilai gizi adalah salah satu parameter terpenting dalam menentukan kualitas makanan, dan sangat penting untuk menguji nilai gizi ketika makanan akan digunakan sebagai makanan tambahan untuk kelompok ibu hamil dan anak balita (Astawan, M., 2008). 
Zat gizi yang terdapat di dalam tempe lebih mudah diserap, dicerna serta lebih mudah digunakan oleh tubuh dibandingkan zat gizi yang terkandung di dalam kedelai. Hal tersebut telah terbukti pada bayi dan balita dengan malnutrisi dan diare kronis. (Tetty, Y. 2013; Karunia Putri, 2013; Afrisanti, D. W., 2010).

Rekomendasi Kementerian Kesehatan untuk penyediaan PMT, menyatakan bahwa komponen gizi PMT bayi meliputi energi minimal 160 kalori, protein 3,24,8 gram, dan lemak 47,2 gram. Untuk ibu hamil, energi minimal adalah 270 kalori, protein minimal 6 gram, dan lemak minimal 12 gram. Analisis kandungan gizi kue bolu yang disubstitusi dengan tepung ubi ungu dan tepung tempe menunjukkan kandungan protein minimal 7,4 gram/100 gram bahan, kadar lemak 2,2 gram/100 gram bahan, dan kadar karbohidrat 32,6 gram/100 gram bahan.

Hasil penilaian panelis yang menunjukkan bahwa mereka lebih memilih kelompok sampel alternatif ubi jalar ungu 50\%$75 \%$, maka kedua kelompok sampel tersebut pasti dapat digunakan sebagai pilihan PMT untuk ibu hamil serta balita jika dinilai berdasarkan kandungan protein pada produk sebesar 7,4 gram/100 gram pada kelompok sampel 50\%, 8,1 gram/100 gram pada kelompok $75 \%$. Namun, masih perlu ditingkatkan kandungan lemaknya.

Keterbatasan penelitian ini ialah panelis yang digunakan adalah panelis dari kelompok mahasiswa sementara sasaran dari produk penelitian ini ialah kelompok ibu hamil dan balita.

\section{KESIMPULAN DAN SARAN}

Substitusi tepung ubi jalar ungu sebanyak $50 \%$ - $75 \%$ dan tepung tempe $20 \%$ pada pembuatan Bolu Cukke merupakan alternatif PMT lokal yang tepat untuk ibu hamil dan anak balita. Bolu Cukke dengan substitusi tepung ubi jalar ungu merupakan alternatif PMT yang sangat layak untuk ibu hamil dan balita, yang dibutuhkan meningkatkan kandungan lemak maka produk ini akan memenuhi semua persyaratan minimum untuk PMT.

\section{DAFTAR PUSTAKA}

A Astawan, M., 2008. Sehat Dengan Tempe.Panduan Lengkap Menjaga Kesehatan dengan Tempe. PT Dian.
Albab, S. U. dan Susanto, W. H. 2016. Pengaruh proporsi mocaf dengan ubi jalar oranye dan penambahan baking powder terhadap sifat kerupuk cekeremes. Jurnal Pangan dan Agroindustri. 4 (2) : 515-524.

Aristawati, R., Atmaka, W., dan Muhammad, D. R. A. 2013. Substitusi tepung tapioka (Manihot esculenta) dalam pembuatan takoyaki. Jurnal Teknosains. 2 (1) : 5665.

Afrisanti, D. W., 2010. Kualitas Kimia dan Organoleptik Nugget Daging Kelinci dengan Penambahan Tepung Tempe. Surakarta: Universitas Sebelas Maret.

Anton Ramadhan Ketra dan Okta Wulandra. 2015. Subtitusi Tepung Ubi Jalar dalam Pembuatan Bolu Gulung. AGRITEPA, Vol. I, No. 2, Januari-Juni 2015

Bastian, F., Ishak, E., Tawali, A. B., dan Bilang, M. 2013. Daya terima dan kandungan gizi formula tepung tempe dengan penambahan semi refined carrageenan (SRC) dan bubuk kakao. Jurnal Aplikasi Teknologi Pangan. 2 (1) : 3-15.

Dinkes, 2017. Laporan Hasil Pemantauan Status Gizi dan Konsumsi Gizi Tahun 2016.

Dwinaningsih, E. A. 2010. Karakteristik Kimia dan Sensori Tempe Dengan Variasi Bahan Baku Kedelai Beras dan Penambahan Angkak Serta Variasi Lama Fermentasi. Skripsi. Universitas Sebelas Maret. Surakarta.

Ginting,E., Yulifianti,R., M. Jusuf, dan Mejaya,M. 2015. Identifikasi Sifat Fisik, Kimia, dan Sensoris Klon-klon Harapan Ubijalar Kaya Antosiani. Penelitian Pertanian Tanaman Pangan Vol. 34 N1. 1 2015

Hal, M. van. 2000. Quality of sweetpotato flour during processing and storage. Food Rev. Int. 16 (1): 1-37.

James, E. O., Peter, I. A., Charles, N. I., dan Joel, N. 2013. Chemical composition and effect of processing and flour particle size on physicochemical and organoleptic properties of cocoyam (Colocasia esculenta var. esculenta) flour. Nigerian Food Journal. 31(2) : 113-122.

Jiang, X. 2001. Sweet potato processing and product research and development at the Sichuan Academy of Agricultural Sciences. Di dalam: Sweet Potato Post 
Harvest Research and Developme.nt in China. Proc. of an Int. Workshop at International Potato Center, pp 114-126.

A Astawan, M., 2008. Sehat Dengan Tempe.Panduan Lengkap Menjaga Kesehatan dengan Tempe. PT Dian

Albab, S. U. dan Susanto, W. H. 2016. Pengaruh proporsi mocaf dengan ubi jalar oranye dan penambahan baking powder terhadap sifat kerupuk cekeremes. Jurnal Pangan dan Agroindustri. 4 (2) : 515-524.

Aristawati, R., Atmaka, W., dan Muhammad, D. R. A. 2013. Substitusi tepung tapioka (Manihot esculenta) dalam pembuatan takoyaki. Jurnal Teknosains. 2 (1) : 5665.

Afrisanti, D. W., 2010. Kualitas Kimia dan Organoleptik Nugget Daging Kelinci dengan Penambahan Tepung Tempe. Surakarta: Universitas Sebelas Maret.

Anton Ramadhan Ketra dan Okta Wulandra. 2015. Subtitusi Tepung Ubi Jalar dalam Pembuatan Bolu Gulung. AGRITEPA, Vol. I, No. 2, Januari-Juni 2015

Bastian, F., Ishak, E., Tawali, A. B., dan Bilang, M. 2013. Daya terima dan kandungan gizi formula tepung tempe dengan penambahan semi refined carrageenan (SRC) dan bubuk kakao. Jurnal Aplikasi Teknologi Pangan. 2 (1) : 3-15.

Dinkes, 2017. Laporan Hasil Pemantauan Status Gizi dan Konsumsi Gizi Tahun 2016.

Dwinaningsih, E. A. 2010. Karakteristik Kimia dan Sensori Tempe Dengan Variasi Bahan Baku Kedelai Beras dan Penambahan Angkak Serta Variasi Lama Fermentasi. Skripsi. Universitas Sebelas Maret. Surakarta.

Ginting,E., Yulifianti,R., M. Jusuf, dan Mejaya,M. 2015. Identifikasi Sifat Fisik, Kimia, dan Sensoris Klon-klon Harapan Ubijalar Kaya Antosiani. Penelitian Pertanian Tanaman Pangan Vol. 34 N1. 1 2015

Hal, M. van. 2000. Quality of sweetpotato flour during processing and storage. Food Rev. Int. 16 (1): 1-37.
James, E. O., Peter, I. A., Charles, N. I., dan Joel, N. 2013. Chemical composition and effect of processing and flour particle size on physicochemical and organoleptic properties of cocoyam (Colocasia esculenta var. esculenta) flour. Nigerian Food Journal. 31(2) : 113-122.

Jiang, X. 2001. Sweet potato processing and product research and development at the Sichuan Academy of Agricultural Sciences. Di dalam: Sweet Potato Post Harvest Research and Development in China. Proc. of an Int. Workshop at International Potato Center, pp 114-126.

Kemenkes., 2017. Juknis Pemberian Makanan Tambahan. Kementerian Kesehatan RI. Jakarta.

Karunia Putri, Permatasari., 2012. Nugget Tempe Dengan Substitusi Ikan Mujair Sebagai Alternatif Makanan Sumber Protein, Serat dan Rendah Lemak. Semarang : Universitas Diponegoro.

Manjilala dan Sirajuddin. 2018. Daya Terima dan kandungan Gizi Kue Bolu Cukke Subtitusi tepung Ubi Jalar Ungu. Media Gizi Pangan, Vol. 25, Edisi 2, 2018.

Murdiati, A., Anggrahini, S., Supriyanto, Alim, A. 2015. Peningkatan kandungan protein mie basah dari tapioka dengan substitusi tepung koro pedang putih (Canvalia ensiformis L.). Agritech. 35 (3) : 251260.

Murtiningrum, Bosawer, E. F., Istalaksana, P., dan Jading, A. 2012. Karakterisasi umbi dan pati lima kultivar ubi kayu (Manihot esculenta). Jurnal Agrotek. 3 (1) : 1-10.

Puteri, M. D. P. T. G., Hassanaein, T. R., Prabawati, E. K., Wijaya, C. H., dan Mutukumira, A. N. 2015. Sensory characteristics of seasoning powders from overripe tempeh, a solid state fermented soybean. Procedia chemistry. 14 (2015) : 263-269.

Tetty, Y. (2013). Uji daya terima dan nilai gizi mie basah yang dimodifikasi dengan tempe dan wortel. (Skripsi, Universitas Sumatera Utara). Diakses dari http://repository.usu.ac.id/handle/123456 789/39724. 